\title{
Niezgodności a zdarzenia niepożądane jako element oceny jakości opieki długoterminowej
}

\author{
Nonconformities and adverse events as a component \\ of quality assesment of long-term care
}

\author{
ROBERT PIEKARSKI ${ }^{1}$ \\ ${ }^{1}$ Kujawsko-Pomorski Oddział Towarzystwa Promocji Jakości Opieki Zdrowotnej w Polsce \\ DOI: http://dx.doi.org/10.21784/IwP.2018.006 \\ ISSN: 2451-1846
}

\section{Streszczenie:}

Wstęp. Na wstępie porównano terminologię działań naprawczych i zapobiegawczych $\mathrm{w}$ procesie zarządzania jakością ze względu na różne źródła normatywne definicji „niezgodności” i „zdarzenia niepożądanego”. Pojęcia działań naprawczych lub zapobiegawczych zostały również zawarte w dokumentach legislacyjnych (projekt ustawy o jakości w ochronie zdrowia i bezpieczeństwie pacjenta), co może stanowić przełom w podejściu do zagadnień nie tyle niezgodności, ale samego procesu rejestracji zdarzeń niepożądanych.

Przegląd. Bliskoznacznymi terminami do omawianych $\mathrm{w}$ tym artykule są „zdarzenie medyczne” i „błąd medyczny”. Dla uproszczenia, ze względu na obszerność interpretacji prawnych oraz z uwagi na większą przejrzystość i wzbogacenie dobrej praktyki zarządzania, analiza źródeł skupiła się na umiejscowieniu „niezgodności” i „zdarzeń niepożądanych” względem siebie w systemach zarządzania jakością. Trzeba zaznaczyć, że temat nie jest nowy i znane są różne propozycje do katalogu rejestrowanych zdarzeń niepożądanych. Szczególnie w obszarze praktyki pielęgniarskiej są zidentyfikowane i powtarzalne $\mathrm{z}$ różnym prawdopodobieństwem i częstością zdarzenia. Zagadnienia jakości w opiece zdrowotnej są regulowane obecnie $\mathrm{w}$ wielu aktach prawnych. Promowanie inicjatyw 
projakościowych wiązałoby się z wprowadzeniem wymagań jakościowych i systematyczną oceną ich spełnienia.

Wnioski. Systemowe podejście do jakości w opiece zdrowotnej wymaga oceny „niedostatecznej i nie akceptowalnej jakości” oraz wprowadzenia rozwiązań poprawiających jakość usług. Wdrożenie rozwiązań prawnoorganizacyjnych ma za zadanie kompleksowo i w sposób skoordynowany realizować priorytety polityki zdrowotnej w obszarze jakości. Zakres projektowanej regulacji prawnej zakłada wprowadzenie rozwiązań wzakresie m.in. systemowego monitorowania zdarzeń niepożądanych (system monitorowania zdarzeń niepożądanych).

Słowa kluczowe: zdarzenia niepożądane, zarządzanie jakością, analiza przyczyn źródłowych zdarzeń niepożądanych, ocena

\begin{abstract}
:
Introduction. Firstly, in view of various definitions of nonconformities and adverse events, the terminology of corrective and preventive measures in the process of quality management was compared. The concept of corrective or preventive action has also been included in the legislative documents (Health Care Quality Act and Patient Safety Act ) what may be a breakthrough with regard to not noncomformities but rather the registration process of adverse events.

Overview. The "medical event" and "medical error" are very similar terms to those discussed in this article. For reasons of simplification, due to the number and volume of the interpretation of the legislation as well as the greater clarity and improving good management practice, the analysis of the sources focused on the location of "noncomformities " and "adverse events" in relation to one another in quality management systems. It should be noted that the subject is not new and there are various proposals for the catalogue of registered adverse events. E In the field of nursing they are identified and repetitive events with a different degree of probability and frequency . Quality issues in health care are regulated in many legal acts. Promoting proquality initiatives would entail the introduction of quality requirements and a systematic assessment of their fulfillment.
\end{abstract}

Conclusions. A systematic approach to quality in health care requires intorducing such terms of assesment as "unsatisfactory" and "unacceptable 
quality "and the introduction of solutions to improve quality of health care. Implementation of legal and organizational solutions aims at intorducing policy priorities in the area of healthcare quality, comprehensively and in a coordinated way. The scope of the proposed legal regulation assumes the introduction of solutions in the field of systematic monitoring of adverse events (system of monitoring adverse events).

Keywords: Adverse events, quality management, Root Cause Analysis (RCA), assessment of the quality of care, assessment

\section{Wstęp}

Jednym z kryteriów oceny jednostek świadczących opiekę zdrowotną w Polsce przez płatnika (NFZ) jest posiadanie certyfikatów w zakresie usług medycznych.

Podmioty lecznicze, zarówno te publiczne jak i niepubliczne, coraz chętniej wdrażają system zarządzania jakością zgodne z normami serii ISO oraz programami akredytacji, co pozwala na wyróżnienie się i osiągnięcie korzyści dla szpitala zarówno finansowych, jak i pozafinansowych.

Ze względu na specyfikę podmiotów leczniczych norma PN-EN ISO 9001:2015-10 (dotycząca Systemu Zarządzania Jakością) [1] ze względu na dużą popularność musiała być rozszerzona o elementy specyficzne dla branży medycznej. Opracowano więc i opublikowano normę polską (wzorowaną na europejskiej) PN-EN 15224:2013 Systemy zarządzania jakością - EN ISO 9001:2015 dla sektora ochrony zdrowia [2]. Norma PN-EN 15224:2013 uwzględnia wymagania systemu zarządzania jakością PN-EN ISO 9001:2015-10, zalecenia Rady Unii Europejskiej (2009/C 151/01) w sprawie bezpieczeństwa pacjentów (także w opiece długoterminowej), w tym profilaktyki i kontroli zakażeń związanych z opieką zdrowotną, wytyczne EN/TS dotyczące usług medycznych $[3,4]$ oraz wytyczne Centrum Monitorowania Jakości w Ochronie Zdrowia [5]. Dzięki temu podmioty lecznicze będą mogły lepiej zarządzać bezpieczeństwem pacjenta, 
(w tym w opiece długoterminowej) i eliminować pojawiające się zagrożenia, mogące prowadzić do niezgodności.

Bardzo ważnym elementem norm są analizy rodzajów ryzyka i zagrożeń bezpieczeństwa pacjenta, plany zapewnienia bezpieczeństwa oraz nadzór nad zdarzeniami niepożądanymi. Mogą one dotyczyć zarówno spraw medycznych związanych z realizowanymi procesami klinicznymi czy ze świadczeniem usług medycznych, (w tym w opiece długoterminowej), jak i polityki zdrowotnej, spraw organizacyjnych, prawnych czy personalnych. Wyniki analizy przyczyn źródłowych zdarzeń niepożądanych stanowią częściową ocenę jakości opieki.

Norma PN-EN ISO 9001:2015-10 i PN-EN 15224:2013 oraz Program Akredytacji Szpitali [5] przygotowany przez Centrum Monitorowania Jakości w Ochronie Zdrowia to swoista hybryda, która w rzeczywistości spełniała swe zadanie, ale przy stosowaniu dobrej praktyki zarządzania, z uwzględnieniem wymagań modnej i potrzebnej obecnie normy PN-EN ISO/IEC 27001:2017-06 (Technika informatyczna - Techniki bezpieczeństwa - Systemy zarządzania bezpieczeństwem informacji - Wymagania) [6] z elementami RODO [7], czyli nowego unijnego rozporządzenia dotyczącego ochrony danych osobowych.

\section{Przegląd literatury}

\section{Zdarzenie niepożądane}

Zdarzenie niepożądane to szkoda wywołana w trakcie lub $\mathrm{w}$ wyniku leczenia, nie związana $\mathrm{z}$ naturalnym przebiegiem choroby lub stanem zdrowia pacjenta [5] lub zdarzenie wywołane w trakcie lub w efekcie udzielania świadczeń opieki zdrowotnej, niezwiązane $\mathrm{z}$ naturalnym przebiegiem choroby lub stanem zdrowia, powodujące lub mogące spowodować negatywne skutki u pacjenta, w tym zgon, zagrożenie życia, konieczność hospitalizacji lub jej przedłużenie, 
trwały lub znaczny uszczerbek na zdrowiu lub chorobę, wadę wrodzoną lub uszkodzenie płodu [8].

\section{Niezgodności i działania korygujące}

Niezgodność to niespełnienie wymagań [9]. Może być związane z określonymi normami, dokumentacją jakości, przepisami prawnymi, wymaganiami stron kontraktu, klienta oraz innych zainteresowanych. Jako niezgodność można potraktować tylko to, co faktycznie zostało stwierdzone, czyli poparte dowodem obiektywnym.

W sytuacji, gdy wystąpi niezgodność, w tym taka, która wynika $\mathrm{z}$ reklamacji, organizacja powinna [9]:

a) zareagować na niezgodność i jeżeli ma to zastosowanie:

- podjąć działania mające na celu jej kontrolę i skorygowanie jej,

- zająć się konsekwencjami,

b) ocenić potrzebę działań eliminujących przyczyny niezgodności, w celu uniknięcia jej ponownego wystąpienia w tym samym lub innym miejscu poprzez:

- dokonanie przeglądu i analizy niezgodności,

- ustalenie przyczyn niezgodności,

- ustalenie, czy występują lub czy mogłyby wystąpić podobne niezgodności,

c) wdrożyć wszelkie niezbędne działania,

d) dokonać przeglądu skuteczności podjętych działań korygujących,

e) zaktualizować ryzyka i szanse określone podczas planowania, jeśli jest to konieczne,

f) wprowadzić zmiany $w$ systemie zarządzania jakością, jeśli są konieczne.

Działania korygujące powinny być dostosowane do skutków stwierdzonych niezgodności. Organizacja powinna przechowywać udokumentowane informacje jako dowód [1]: 
a) charakteru niezgodności i wszelkich podjętych w ich następstwie działań,

b) wyników podjętych działań korygujących.

Działania naprawcze lub zapobiegawcze (wg projektu ustawy o jakości w ochronie zdrowia i bezpieczeństwie pacjenta [8] przedstawia poniższa rycina 1.

\section{Zapobieganie}

Niezgodność

Działania korygujące

\section{Profilaktyka}

Zdarzenie niepożądane

Plan działań

Rycina 1. Porównanie terminologii działań naprawczych i zapobiegawczych $w$ procesie zarządzania jakością $w$ normie PN-EN ISO 9001:2015-10 [3] i w zapisach $w$ Projekcie założeń do projektu ustawy o jakości w ochronie zdrowia i bezpieczeństwie pacjenta.

Źródło: opracowanie własne na podstawie Projektu ustawy o jakości w ochronie zdrowia i bezpieczeństwie pacjenta [8].

Bliskoznaczne terminy związane $\mathrm{z}$ niezgodnościami i zdarzeniami niepożądanymi przedstawia rycina 2 . 


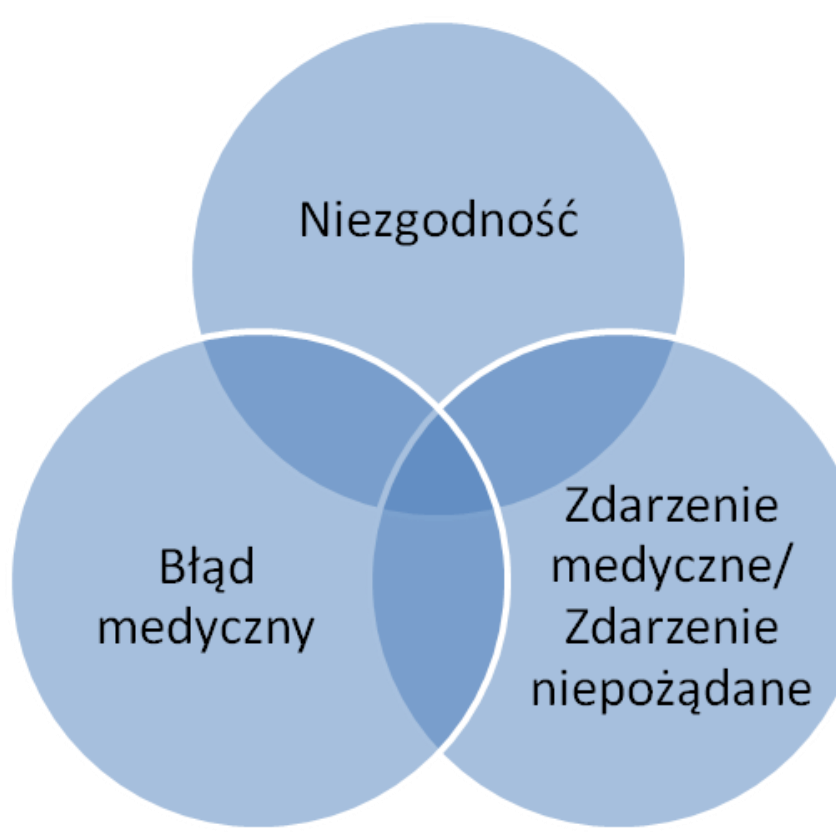

Rycina 2. Porównanie bliskoznacznych terminów dotyczących niezgodności i zdarzeń niepożądanych.

Źródło: opracowanie własne.

Zdarzeniem medycznym są: [10]

- zakażenie pacjenta biologicznym czynnikiem chorobotwórczym,

- uszkodzenie ciała pacjenta,

- rozstrój zdrowia pacjenta,

- śmierć pacjenta,

- jeżeli nastąpiły wskutek niezgodnych z aktualną wiedzą medyczną:

- diagnozy, jeżeli spowodowała ona niewłaściwe leczenie albo opóźniła właściwe leczenie, przyczyniając się do rozwoju choroby,

- leczenia w tym wykonania zabiegu operacyjnego,

- zastosowania produktu leczniczego lub wyrobu medycznego.

Zdarzenie medyczne tłumaczone jest $w$ orzecznictwie [11] jako niepożądane następstwo zabiegu, spowodowane szczególnymi okolicznościami objętymi tzw. ryzykiem medycznym. 
Pojęcie to nie odnosi się natomiast wprost do błędu ludzkiego, koncentruje się w głównej mierze na organizacji procesu leczenia i w tym zakresie wiąże się z pojęciem winy organizacyjnej [12]. Błąd medyczny oraz „błąd w sztuce” są pojęciami, które dotyczą działalności danej osoby wykonującej zawód medyczny i odnoszą się do uchybień popełnionych przez nią w procesie leczenia, naruszenia reguł postępowania ocenianych $\mathrm{w}$ kontekście nauki i praktyki medycznej. Najlepszym sposobem niedopuszczenia do zdarzenia niepożądanego, a w następstwie często do niezgodności, jest podejmowanie działań profilaktycznych (zapobiegawczych), co przedstawia poniższa rycina 3 .

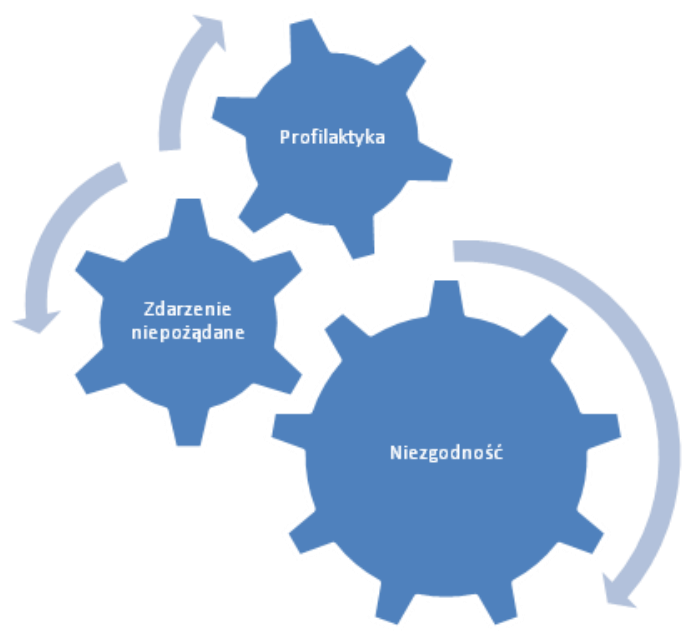

Rycina 3. Sekwencja: działania zapobiegawcze, korekcyjne i korygujące.

Źródło: opracowanie własne.

Wyspecyfikowano propozycję do katalogu rejestrowanych zdarzeń niepożądanych w obszarze praktyki pielęgniarskiej [13]:

1. Niewłaściwy pacjent.

2. Odcewnikowa infekcja łożyska naczyniowego.

3. Sepsa po zabiegu operacyjnym. 
4. Upadki w szpitalu.

5. Wypadnięcie z łóżka.

6. Komplikacje wywołanie nieprawidłowym podnoszeniem pacjenta.

7. Samowolne oddalenie się pacjenta ze szpitala.

8. Błędy związane z pobieraniem próbek krwi, rozbieżności wykryte podczas kontroli zgodności krwi, obcogrupowe przetoczenie krwi.

9. Niewłaściwy lek, niewłaściwa droga podania, niewłaściwy pacjent, niewłaściwe połączenie z innym lekiem.

10. Samobójstwo.

11. Inne zgodnie $\mathrm{z}$ definicją.

\section{Standardy jakości (zarządzania jakością) w ochronie zdrowia}

Projekt założeń do ustawy o jakości w ochronie zdrowia i bezpieczeństwie pacjenta określa, że [8]:

- system monitorowania jakości i bezpieczeństwa ma być standardem jakości w ochronie zdrowia,

- w pierwszej kolejności obejmie szpitale, a w przyszłości pozostałe podmioty wykonujące działalność leczniczą.

Standardy jakości (zarządzania jakością) w ochronie zdrowia przedstawia rycina 4. 


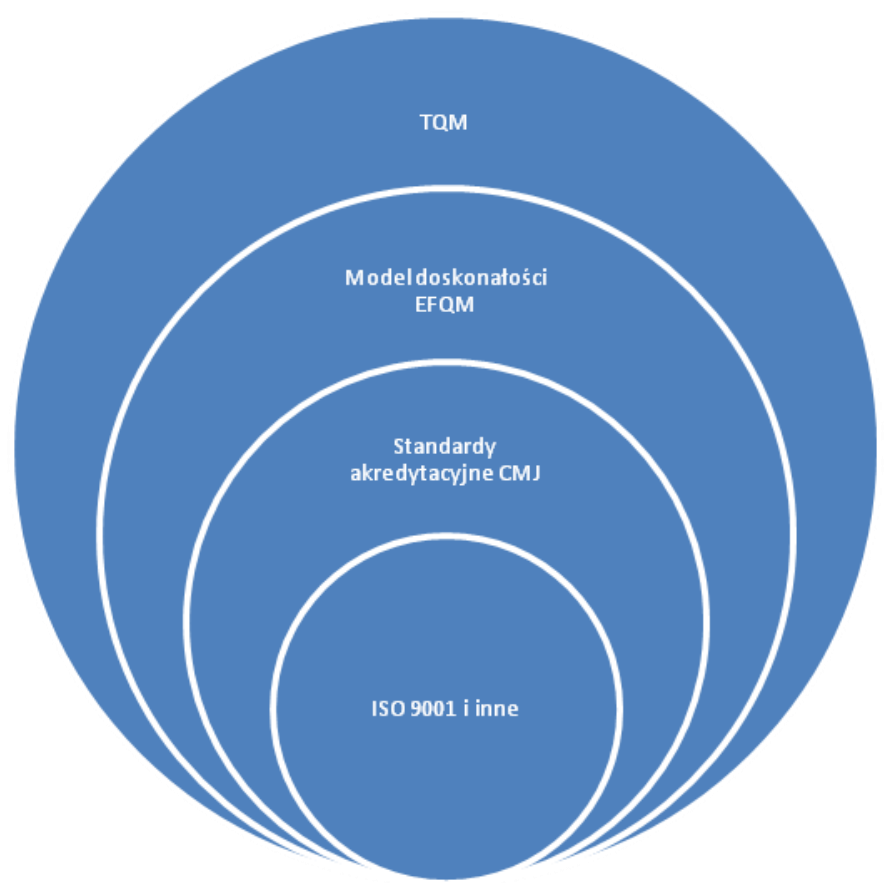

Rycina 4. Modele (standardy) kompleksowych, zintegrowanych systemów zarządzania jakością.

Źródło: opracowanie własne.

Projekt założeń do ustawy o jakości w ochronie zdrowia i bezpieczeństwie pacjenta [8]:

- w sposób kompleksowy ujmuje różne zagadnienia dotyczące jakości, - wprowadza wiele zmian, które wpływają na funkcjonowanie placówek, a także wzrost poczucia bezpieczeństwa przez pacjentów, tj. obowiązek monitorowania i raportowania wartości wskaźników jakości leczenia czy także nowy system monitorowania zdarzeń niepożądanych,

- podmioty prowadzące działalność leczniczą, które - aby świadczyć usługi medyczne finansowane ze środków publicznych - będą musiały uzyskać tzw. autoryzację; pojawia się pytanie co jest obecnie, przed autoryzacją? 
- jej elementem stanie się wewnętrzny system monitorowania jakości i bezpieczeństwa; pojawia się kolejne pytanie jakie są wewnętrzne systemy?

\section{Akredytacja (Autoryzacja)}

Na początku systemem akredytacji (autoryzacji) mają zostać objęte wszystkie podmioty lecznicze oferujące stacjonarne i całodobowe świadczenia zdrowotne, które mają zawarte umowy z Narodowym Funduszem Zdrowia (z okresem przejściowym), a z czasem również pozostałe. Podmiot objęty systemem autoryzacji będzie wnosił coroczną opłatę za uczestnictwo w systemie (do dnia 31 stycznia) w wysokości przeciętnego miesięcznego wynagrodzenia. System akredytacji nie jest niczym nowym w polskiej ochronie zdrowia. Z powodzeniem funkcjonuje już od kilkunastu lat w formie standardów akredytacyjnych i realizowanych na ich podstawie wizytacji. Kolejną ważną zmianą jest wprowadzenie wzrostu poziomu finansowania ze środków publicznych w wymiarze dodatkowego 1\% wartości umowy ze względu na fakt posiadania certyfikatu akredytacyjnego. Przy czym udział w systemie akredytacji w dalszym ciągu pozostanie dobrowolny.

Zewnętrzną i wewnętrzną ocenę jakości przedstawiają rycina 5 i rycina 6. 


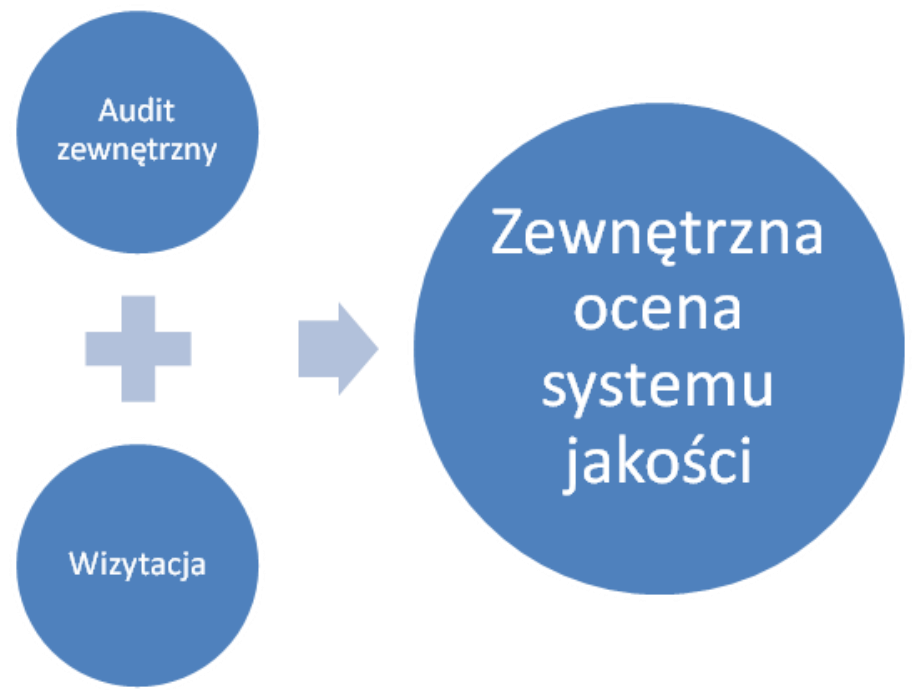

Rycina 5. Zewnętrzna ocena systemu zarządzania jakością. Źródło: opracowanie własne.

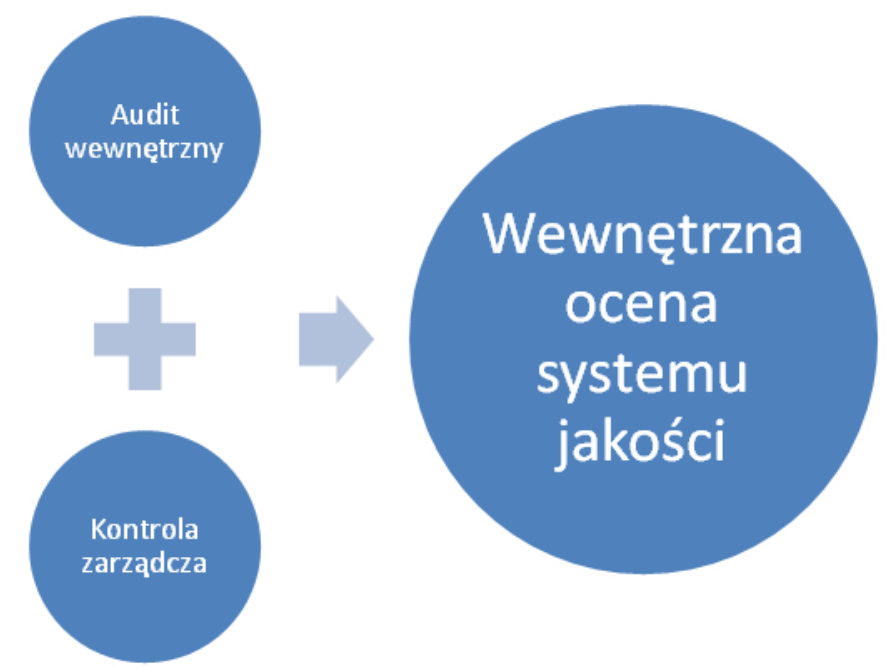

Rycina 6. Wewnętrzna ocena systemu zarządzania jakością. Źródło: opracowanie własne. 
EN 15224:2012 jest europejskim, resortowym standardem systemu zarządzania jakością $\mathrm{w}$ branży medycznej (wydano odpowiednik normy polskiej PN-EN 15224:2013). Ma on zastosowanie we wszystkich organizacjach medycznych: badawczych, kształceniowych oraz tych, które realizują procesy kliniczne bezpośrednio związane z pacjentem, czyli :

- laboratoriach,

- pracowniach diagnostycznych,

- klinikach,

- szpitalach,

- ambulatoriach,

- specjalistycznych i podstawowej opiece zdrowotnej.

Wymagania tego standardu opierają się na wymaganiach ISO 9001 - System zarządzania jakością.

Norma PN-EN 15224:2013 bazuje na zasadach wynikających z teorii zarządzania, kontroli zarządczej oraz w dużej mierze na standardach akredytacyjnych. Zarządzanie ryzykiem klinicznym jest podstawowym składnikiem systemu zarządzania jakością w ochronie zdrowia.

Rozwiązania w ustawie (projekcie) mają [8]:

- zapewnić podmiotom leczniczym, instytucjom nadzorującym oraz pacjentom dostęp do wiarygodnej, obiektywnej i porównywalnej informacji o jakości świadczonej opieki,

- dać możliwość leczenia się w placówkach, w których opieka, jakość i bezpieczeństwo usług jest na wysokim poziomie.

Pojawia się pytanie jaki jest poziom tych usług obecnie? Wykładniki akceptowalnego poziomu jakości prezentuje rycina 7. 


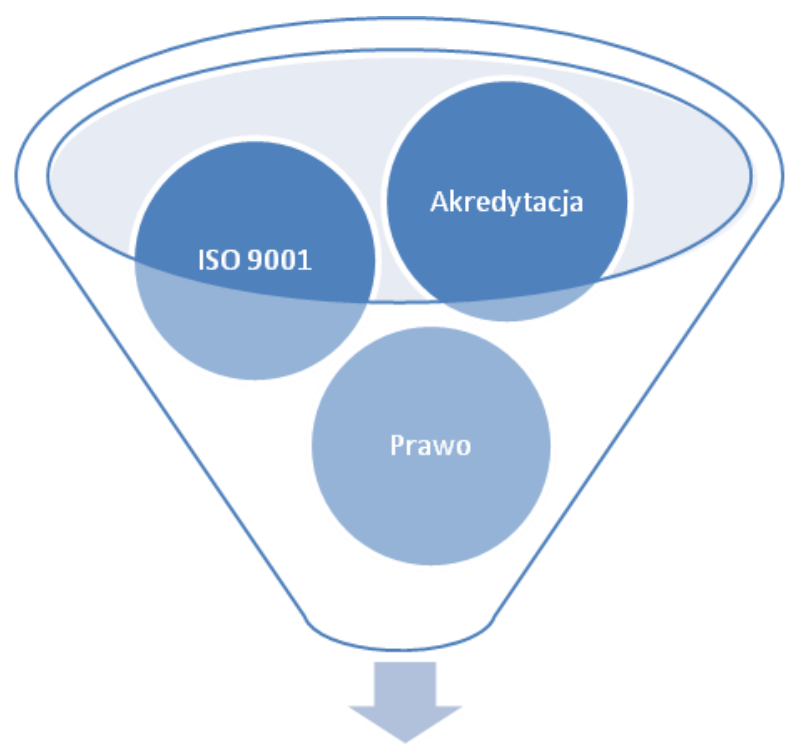

Akceptowalny poziom jakości
usług medycznych

Rycina 7. Wykładniki systemu zarządzania jakością.

Źródło: opracowanie własne.

Obecne niektóre kluczowe problemy funkcjonowania systemów zarządzania jakością $\mathrm{w}$ podmiotach leczniczych oraz otoczenia warunkującego poprawę tego poziomu jakości to [8]:

1. Niewystarczające regulacje prawne $\mathrm{i}$ problem $\mathrm{z}$ ich egzekwowaniem.

2. Brak dostatecznej wiedzy o poziomie jakości.

3. Niedostateczne zdefiniowanie odpowiedzialności za niewłaściwą jakość.

4. Niedostateczna motywacja do poprawy jakości.

5. Niedostateczne wdrożenie procedur postępowania i niewłaściwe zarządzanie.

6. Niewystarczające monitorowanie i kontrola podmiotów, które wykonują działalność leczniczą. 
Wiedza o poziomie jakości wskazuje na następujące sposoby rozwiązania problemu [8]:

- Wprowadzenie obowiązku monitorowania i raportowania klinicznych wskaźników jakości oraz zdarzeń niepożądanych.

- Dostęp osób $\mathrm{z}$ poza systemu do wyników monitorowania i wskaźników klinicznych.

- Motywowanie do zgłaszania zdarzeń niepożądanych przez personel bez konsekwencji dyscyplinarnych, zawodowych i karnych.

- Możliwość zgłaszania zdarzeń przez np. pacjentów.

Pojawia się pytanie w jaki sposób pacjenci będą mogli to zgłaszać? Odpowiedzialność za niewłaściwą jakość wymaga następującego rozwiązania problemu [8]:

-Wprowadzenie nowych zasad i trybu funkcjonowania systemu monitorowania zdarzeń niepożądanych i określenie odpowiedzialności w tym zakresie.

-Określenie wewnętrznego systemu autoryzacji i systemu monitorowania jakości i bezpieczeństwa wraz z odpowiedzialnością w tym zakresie.

Podstawowe elementy zapewniania jakości w placówce ochrony zdrowia to [14]:

- Kontrola jakości (Quality Control) - polega zwykle na monitorowaniu oraz stwierdzeniu określonych cech produktu lub usługi. Przykładem kontroli jakości może być program kontroli zakażeń szpitalnych, obejmujący jedynie aktywne monitorowanie zakażeń na podstawie wyników posiewów, badań radiologicznych, zleceń antybiotyków czy też kart gorączkowych, bez wdrażania działań zmniejszających ryzyko wystąpienia zakażeń szpitalnych, takich jak system szkoleń pracowników czy też szpitalna polityka antybiotykowa [14].

- Ocena jakości (Quality Assessment) - opiera się na realnym poznaniu jakości usług świadczonych $\mathrm{w}$ danym podmiocie leczniczym. Najczęstszą formą oceny jakości są badania satysfakcji 
pacjentów, które mogą być powiązane $\mathrm{z}$ efektami procedur medycznych poddawanych ocenie [14].

- Poprawa jakości (Quality Improvement) - poza analizą sytuacji bieżącej, obejmuje określenie przyczyn występowania określonych dysfunkcji oraz propozycje metod poprawy a następnie monitorowanie uzyskanych rezultatów. Przykładem zastosowania tego podejścia w szpitalu może być poprawa opieki nad pacjentami na oddziale chirurgicznym, polegająca na skróceniu czasu oczekiwania na zabieg, aby minimalizować stres związany $\mathrm{z}$ poddaniem się zabiegowi oraz zmniejszyć ryzyko wystąpienia zakażeń szpitalnych, a przez to - zwiększyć satysfakcję pacjenta i jednocześnie ograniczyć koszty jego pobytu w placówce [14].

- Zapewnienie jakości (Quality Assurance) - to część zarządzania jakością, ukierunkowana na zwiększenie zdolności do spełniania wymagań dotyczących jakości [9], która zwraca szczególną uwagę na zapobieganie ewentualnym problemom związanym z realizacją usługi medycznej. Zapewnienie jakości wiąże się więc z koniecznością wdrażania różnego rodzaju programów np. programu zapewnienia jakości bezpiecznego napromieniowania, obejmującego: systematyczną kontrolę parametrów fizycznych i technicznych aparatury do radioterapii, opracowanie zaleceń formalnoprawnych dokumentacji, procesu świadczenia usług oraz procedur reagowania w sytuacjach awaryjnych [9].

- Zarządzanie jakością (Quality Management) - polega na systematycznym działaniu wszystkich pracowników danej organizacji, które ma na celu poprawę jakości opieki nad pacjentem. Zarządzanie jakością nie jest jedynie kontrolą - obejmuje planowanie jakości przez specjalny zespół pracowników zatrudnionych w danym podmiocie leczniczym, doskonalenie jakości (analizę przyczyn powstałych dysfunkcji oraz wdrożenie rozwiązań powstałych problemów), a także pomiar jakości, a więc ocenę organizacji w odniesieniu do jej wszystkich jednostek organizacyjnych [14]. 
Cztery główne filary systemu zapewnienia jakości w ochronie zdrowia i bezpieczeństwa pacjenta [8] to:

- system autoryzacji,

- system monitorowania zbierania zdarzeń niepożądanych,

- system monitorowania klinicznych wskaźników jakości,

- system akredytacji.

Fundament funkcjonowania podmiotów leczniczych w Polsce prezentuje rycina 8 .

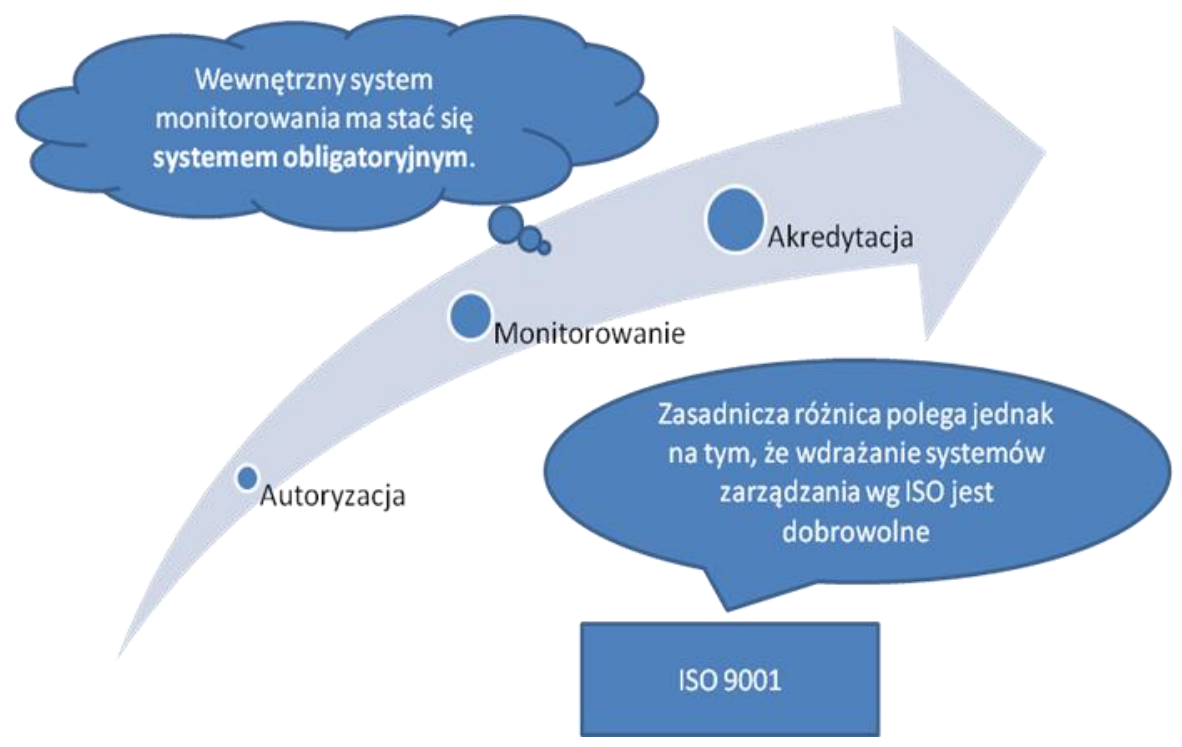

\section{Rycina 8. Fundament funkcjonowania podmiotów leczniczych} w Polsce.

Źródło: opracowanie własne na podstawie projektu założeń do projektu ustawy o jakości w ochronie zdrowia i bezpieczeństwie pacjenta [8] oraz normy PN-EN ISO 9001:2015-10 [1]. 
Kryteria autoryzacji oraz metodologia oceny ich spełniania będą obejmowały rożne obszary działania [8], tj.

- sposób zarządzania majątkiem,

- sterylizację,

- politykę lekową,

- personel,

- sposób określania i monitorowania wskaźników działalności klinicznej.

Szczegółowy zakres oceny określi w rozporządzeniu Minister Zdrowia. Będzie on obligatoryjny od 1 stycznia 2020r.

System monitorowania zdarzeń niepożądanych zakłada następujące aspekty [8]:

- Poprawę poziomu jakości i bezpieczeństwa - poprzez prowadzenie wewnętrznego systemu monitorowania jakości i bezpieczeństwa udzielanych świadczeń opieki zdrowotnej.

- Będą nim objęte podmioty lecznicze prowadzące szpital, niezależnie od faktu korzystania ze środków publicznych (w rodzaju stacjonarne i całodobowe świadczenia zdrowotne szpitalne).

- System monitorowania ma polegać na identyfikowaniu i analizie zdarzeń niepożądanych oraz poznawaniu ich przyczyn, na podstawie których podejmowane będą działania naprawcze lub zapobiegawcze.

System ma być oparty na dwóch poziomach nadzoru:

- zewnętrznym - prowadzonym przez agencję (zdarzenia o wysokim ryzyku),

- wewnętrznym - prowadzonym przez szpital (wszystkie zdarzenia niepożądane).

Zgłaszane zdarzenia niepożądane będą punktowane na podstawie stopnia ich dolegliwości dla pacjenta i prawdopodobieństwa występowania. W oparciu o zgłoszenia Agencja do Spraw Jakości Opieki Zdrowotnej i Bezpieczeństwa Pacjenta opracuje raporty i wytyczne poprawy jakości, bezpieczeństwa pacjenta $\mathrm{w}$ formie ogólnodostępnych komunikatów jakości. Swobodę w zgłaszaniu przez szpital zdarzeń do rejestru ma 
ułatwić wprowadzenie rozwiązań o niesankcjonowaniu osób, które zgłaszają zdarzenia, przez zwolnienie ich $\mathrm{z}$ odpowiedzialności dyscyplinarnej, zawodowej i karnej, jeśli tylko zdarzenie nie powstało na skutek winy umyślnej lub zaniedbania. Oprócz informacji czerpanych bezpośrednio od podmiotów leczniczych agencja będzie mogła się dowiedzieć o zjawiskach niezgodnych ze standardami bezpieczeństwa również od pacjentów, rodziny, osób bliskich czy obywateli. W tym celu stworzy aplikację internetową [8].

Istnieją jednak obawy, czy pojawienie się kolejnego rejestru, do którego należy przesyłać dane, obok wielu już istniejących, nie przełoży się na i tak już dużą biurokrację. Obawę tę może uzasadniać fakt, że mimo wzorowania się twórców projektu na światowych praktykach trudno znaleźć w nim rozwiązania oparte na budowaniu wewnętrznej kultury bezpieczeństwa (tzw. safe culture) popularnej w Europie i Stanach Zjednoczonych.

\section{Wnioski}

Zdarzenia niepożądane najlepiej weryfikuje się stosując analizy przyczyn źródłowych (RCA-Root Cause Analysis), tj. analizy przyczyn jako powodu wystąpienia zdarzenia niepożądanego. Analiza przyczyn jako metoda jest również stosowana przy określaniu tzw. zdarzeń jeszcze nie zaistniałych (ang. near misses), jako działanie zapobiegawcze, co mogłoby wpłynąć na zdrowie pacjenta [15]. RCA to bardzo użyteczne narzędzie do analiz przyczyn źródłowych $\mathrm{w}$ zintegrowanych systemach zarządzania w szpitalach posiadających akredytację i certyfikację zgodności z norami międzynarodowymi serii ISO (szczególnie PN-EN ISO 9001:2015-10) oraz normy PN-EN 15224:2013. Zdarzenia niepożądane więc są wplecione w procedurę nadzoru nad niezgodnościami ze wszelkimi przejawami podejmowanych działań zapobiegawczych jak również korekcyjnych i korygujących wg normy PN-EN ISO 9001:2015-10.

Analiza przyczyn źródłowych jest to proces ustalania i wyjaśniania, zbierania i analizowania danych jakościowych 
i ilościowych, a także dodatkowych czynników mogących mieć wpływ na niepożądanych skutek. RCA wiąże się $\mathrm{z}$ zaleceniami podjęcia działań, które mają przynieść konkretną poprawę bezpieczeństwa [15]. Nie określa pracowników lub osób biorących udział w zdarzeniu odpowiedzialnych za wystąpienie zdarzenia niepożądanego; nie służy ich ujawnieniu i identyfikacji. Najważniejsze są aspekty organizacyjne, procesy wewnętrzne, komunikacja $\mathrm{w}$ szpitalu oraz technologie i sprzęt medyczny.

Wyniki analizy przyczyn źródłowych zdarzenia niepożądanego są częścią wewnętrznej dokumentacji szpitala w obszarze poprawy jakości jednak nie stanowią elementu historii choroby (nie są udostępniane).

Utrzymywanie takich podstaw podejścia systemowego w analizie przyczyn źródłowych zdarzenia niepożądanego stanowi o jej powodzeniu i skuteczności. By zachować systemowe podejście do zdarzenia niepożądanego, określając przebieg zdarzenia, nie wspomina się nigdy o rzeczywistych pracownikach (lub biorących udział w zdarzeniu), nie podaje danych osobowych, ani funkcji w strukturze organizacyjnej, najlepiej również gdy nie określa się dat zdarzenia [15].

\section{Bibliografia/Bibliography:}

1. PN-EN ISO 9001:2015-10 - wersja polska. Systemy zarządzania jakością - Wymagania. PKN, Warszawa 2016.

2. PN-EN 15224:2017-02 - wersja angielska. Systemy zarządzania jakością - EN ISO 9001:2015 dla sektora ochrony zdrowia. PKN, Warszawa 2017.

3. Sprawozdanie pt „Najważniejsze ustalenia i zalecenia dotyczące systemów zgłaszania zdarzeń dotyczących bezpieczeństwa pacjentów i wyciągania wniosków z takich zdarzeń w Europie" (Sprawozdanie Podgrupa ds. Zgłaszania Zdarzeń i Wyciągania 
Wniosków PSQCWG Komisji Europejskiej maj 2014 r.), http://ec.europa.eu/health/patient_safety/policy/index_en.htm, 29.03.2018r.

4. Zalecenia Rady Europy 2009/C151/01 w sprawie bezpieczeństwa pacjentów, w tym profilaktyki i kontroli zakażeń związanych z opieką zdrowotną, https://eur-lex.europa.eu/legalcontent/PL/TXT/?uri=CELEX:32009H0703(01), 29.03.2018r.

5. Program Akredytacji. Szpitale. Zestaw standardów. Centrum Monitorowania Jakości w Ochronie Zdrowia, Kraków 2009 (wydanie wznowione 2016).

6. PN-EN ISO/IEC 27001:2017-06 - wersja angielska. Technika informatyczna - Techniki bezpieczeństwa - Systemy zarządzania bezpieczeństwem informacji - Wymagania. PKN, Warszawa 2017.

7. Rozporządzenie Parlamentu Europejskiego i Rady (UE) 2016/679 z dnia 27 kwietnia 2016 r. w sprawie ochrony osób fizycznych w związku z przetwarzaniem danych osobowych i w sprawie swobodnego przepływu takich danych oraz uchylenia dyrektywy 95/46/WE (ogólne rozporządzenie o ochronie danych).

8. Projekt założeń do projektu ustawy o jakości w ochronie zdrowia i bezpieczeństwie pacjenta $\mathrm{Z}$ 20.01.2017, https://legislacja.rcl.gov.pl/projekt/12294407, 29.03.2018r.

9. PN-EN ISO 9000:2015, Systemy zarzq̨dzania jakościq. Podstawy i terminologia, 2016, Polski Komitet Normalizacyjny, Warszawa 2016.

10. Ustawa z dnia 6 listopada 2008 r. o prawach pacjenta i Rzeczniku Praw Pacjenta (Dz.U.2017.0.1318).

11. Wyrok z dnia 11 grudnia 2002 roku, sygn. akt I CKN 1386/00, Sąd Najwyższy; Wyrok z dnia 18 kwietnia 2002 roku, sygn. akt I ACa 214/02, Sąd Apelacyjny w Krakowie; Wyrok z dnia 13 września 1937 roku, Sąd Najwyższy; Wyrok z dnia 14 grudnia 1973 roku, 
sygn. akt II CR 692/73, Sąd Najwyższy; Wyrok z dnia 11 maja 1983 roku, sygn. akt IV CR 118/83, Sąd Najwyższy; Wyrok z dnia 10 grudnia 1952 roku, sygn. akt 584/52, Sąd Najwyższy, http://www.pociecha.com.pl , 29.03.2018r.

12. Orzeczenie Sądu Okręgowy w Katowicach Sygn. akt IC 46/11 (Zarządzenie, uzasadnienie $\mathrm{z}$ dnia 24.01.2014r., https://orzeczenia.ms.gov.pl/content/\$N/151520000000403_I_C_0 00046_2011_Uz_2014-01-24_001, 29.03.2018r.

13. Kruk-Kupiec G. Zalecenia Konsultanta Krajowego w dziedzinie pielęgniarstwa „Dla dobrej praktyki pielęgniarskiej bezpieczny szpital - bezpieczny pacjent. Zarządzanie ryzykiem zdarzeń niepożądanych. Projekt bezpiecznej praktyki medycznej”. 2011, arch.nipip.pl/index.php/prawo/opiniekk/w-dz-

pielegniarstwa/1753-bezpieczny-pacjent, 29.03.2018r.

14. Staszewski, R., Kautsch M. Jakość certyfikowana. W: Kautsch M. (red.), Zarządzanie w opiece zdrowotnej. Nowe wyzwania. Oficyna a Wolters Kluwer business, Warszawa 2010.

15. Kutryba B., Kutaj-Wąsikowska H., Tombarkiewicz M. Analiza przyczyn źródłowych zdarzeń niepożądanych (Root Cause Analysis - RCA). Przewodnik dla zespołów jakości, lekarzy, pielęgniarek, oraz innych osób przeprowadzających RCA. Adaptacja na podstawie opracowania Duńskiego Towarzystwa Bezpieczeństwa Pacjentów (DanskSelskab for Patientsikkerhed). Centrum Monitorowania Jakości w Ochronie Zdrowia w Krakowie, Kraków 2015, http://bezpiecznypacjent.cmj.org.pl/wpcontent/uploads/2016/02/Broszura-zdarzenianiepo\%C5\%BC\%C4\%85dane.pdf, 29.03.2018r. 